\title{
Microalgae Derived Alkenones and their Applications
}

\author{
Kyle McIntosh ${ }^{1}$, David J Terrero ${ }^{2}$, Rahul Khupse ${ }^{3}$ and Amit K Tiwari ${ }^{1 *}$ \\ ${ }^{1}$ Department of Pharmacology and Experimental Therapeutics, University of Toledo, USA \\ ${ }^{2}$ Pontificia Universidad Católica Madre y Maestra, Dominican Republic \\ ${ }^{3}$ College of Pharmacy, University of Findlay, Findlay, USA
}

Submission: August 27, 2019; Published: September 06, 2019

Corresponding author: Amit K Tiwari, Department of Pharmacology and Experimental Therapeutics, College of Pharmacy \& Pharmaceutical Sciences, University of Toledo, Ohio 43614,Email: amit.tiwari@utoledo.edu; Tel:+1-419-383-1913; Fax:+1-419-383-1909

\begin{abstract}
Marine microalgae and their extracts, in recent years, have found applications, including use as biofuels, medicines and food. Recently, alkenones, a unique chain of long-chain lipids, extracted from Isochrysis microalgae, has emerged as a useful by product. This is the first review that summarizes the potential applications and limitations of alkenones use in paleoclimatology, biofuel, personal care industry and therapeutics.

Keywords: Alkenones; Microalgae; Paleoclimatology; Biodiesel; Personal care products

Abbreviations: $\mathrm{CO}_{2}$ : Carbon Dioxide; HPLC: High-Performance Liquid Chromatography; MAAs: Mycosporine-like Amino Acids; EPA: Eicosapentaenoic Acid; DHA: Docosahexaenoic Acid
\end{abstract}

\section{Introduction}

Marine algae have many advantages when compared to traditional terrestrial plant agriculture. One significant advantage is the lack of soil for growth; thus, algae do not compete with agricultural products for a limited growth area [1]. Furthermore, marine algae consume less water compared to land crops and yield a high production per acre due to their high growth rate. For these reasons, culturing algae, compared to terrestrial plants, should be cost-effective. Microalgae species or plankton are the primary producer of organic matter in aquatic environments by photosynthesis and provide a food source for the aquatic habitat. Microalgae can use $\mathrm{CO}_{2}$, nutrient salts, organic matter, trace elements and they convert energy from the sun by photosynthesis [2].

Microalgae can be found in either freshwater or seawater environments. When exposed to extreme conditions, marine microalgae must adapt to new environments [3]. They typically produce diverse, secondary biologically active metabolites that are not present in terrestrial plants [4]. There are an estimated 200,000 to several million species of microalgae [5], and only 40,000 have been identified [2], and their unique metabolites could be of importance in the development of cosmetic products. Currently, marine microalgae derived from harvested seaweed is used as animal feed, wastewater treatment, carbon dioxide sequestration, biofuels, pharmaceuticals and nutraceutical and cosmetics applications [6].

\section{Compounds obtained from Marine Microalgae}

Several extraction and analytical techniques have been used in the past to extract beneficial compounds from marine microalgae. The Soxhlet extraction has been used for nonpolar, lipid derivatives, while High-Performance Liquid Chromatography (HPLC) can identify carbohydrates, carotenoids, fatty acids and mycosporine-like amino acids from marine algae [7]. A recent review [8] discussed additional extraction techniques, including supercritical-fluid extraction, enzyme-assisted extraction and microwave-assisted extraction. Several compounds of interest were extracted from algae, including mycosporine-like amino acids (MAAs) [9], glucosyl glycerols, polysaccharides/sulfated polysaccharides [10], polyphenols, and lipids [11] among others. Many of these compounds have been reported to have anti-inflammatory, antioxidant, and photo protection [12], anti-diabetic, anti-microbial, anti-cancer $[13,14]$, gastroprotective and neuroprotective efficacy. The focus of this mini-review paper will be on the alkenones derived from Isochrysis galbana.

\section{What are Alkenones?}

Currently, only four strains of haptophytes from the order of Isochrysidales: Emiliania huxleyi, Gephryocapsa oceanica, Isochrysis galbana, and Chrysotila lamellose, are known to produce compounds referred to as either alkenes or alkenones [15]. Both 
Chrysotila lamellose and Isochrysis galbana can produce $\mathrm{C}_{31}, \mathrm{C}_{33}$ $\mathrm{C}_{37}$, and $\mathrm{C}_{38}$ alkenes [16], as well as $\mathrm{C}_{37}-\mathrm{C}_{39}$ alkenones [17]. The difference between alkenes and alkenones is in the unsaturated methyl or ethyl ketone group [18]. The Isochrysis sp. is a non-toxic food source for cultivated marine animals [19] as it produces essential polyunsaturated fatty acids, such as Eicosapentaenoic acid and docosahexaenoic acid for the growth and development of fish larvae [20]. This marine alga is characterized by a lack of toxins, a quick growth rate and salinity tolerance [21]. Also, Isochrysis sp. lack cell walls, allowing for easier lipid extraction compared to other algae [22]. The most common cultured version is the Tahitian strain, "T-iso" [23].
Alkenones are identified by a methyl or ethyl ketone group, two to four non-methylene trans-double bonds and by long hydrocarbon chains (36-40 carbons)[24]. These alkenones were discovered to have a high melting temperature $\left(71.1-77.4^{\circ} \mathrm{C}\right),[25]$ and were compatible with other commonly used waxes in lipsticks, lip balms, and creams, thereby making them a potential wax-like compound for personal care products. Figure 1 shows the three major structures of alkenones isolated from Isochrysis galbana. The relative percentage of 0.1 grams of mixed alkenones derived from purified Isochrysis biomass was reported as $26.1 \%$ (37:3 methyl alkenones), 62.7\% (37:2 methyl alkenones), and $15.7 \%$ (38:2 ethyl alkenones) (Figure 1) [26].

Figure1: Three common structures of alkenones derived from Isochrysis galbana when isolated for biofuel. The relative percentage from 0.1 gram of mixed alkenones was previously reported as $26.1 \%$ (37:3 methyl alkenones), $62.7 \%$ (37:2 methyl alkenones), and 15.7\% (38:2 ethyl alkenones) (26).

\section{Current Uses of Alkenones}

\section{Paleoclimatology}

It is essential to accurately monitor climate change-driven trends that occur in the ocean. By analyzing the preserved alkenones and other lipids in the ocean bottom sediments, the alkenones structure can reflect the water temperature in that particular zone [26]. The number of unsaturated bonds in an alkenone is known to increase when the microalgae are grown or maintained at low temperatures [27]. This characteristic, an unsaturated index formula, termed $\mathrm{U}^{\mathrm{k}^{\prime}}$, is calculated as a parameter of the ratio of $\mathrm{C}_{37: 2}$ to $\mathrm{C}_{37: 3}$ alkenones $[28,29]$. The significant correlation between alkenones abundances and sea surface temperatures make the alkenones a widely used biomarker for paleoclimate studies. It should be noted that a common misconception is that distinct alkenones signature alone can directly identify specific species of microalgae. This theory was disproved after sampling 15 alkenone-containing lake surfaces indicated that DNA fingerprinting is a better approach to identifying species [30].

\section{Biofuel}

Isochrysis sp. is commercially cultivated algae grown worldwide [31], and having an algae strain that can yield high lipid production is a desirable characteristic for biodiesel production. Biodiesel derived from algae was shown to be less toxic in seawater when compared to conventional jet and marine diesel fuels [32]. In addition to having lower amounts of sulfur and particulate matter emissions, biodiesel increases performance in brake thermal efficiency (ratio of brake power to the thermal energy input from the fuel) [33]. Biodiesel also improved brake - specific energy consumption (a measure of the combustion quality of the fuels) performance for a single-cylinder, 4-stroke, air-cooled, direct injection diesel engine.

Lipids are an excellent source for making biofuel as they store high amounts of energy. Isochrysis galbana has an oil content up to $25-33 \%$ dry weight [34]. For a discussion of lipid extraction technologies, see [35] A six-step protocol has been published that provides details about isolating and purifying alkenones from commercially available Isochrysis paste. Alone, alkenones with long chains of 37-39 carbons are not suitable for use jet fuel, but once converted to 8-13 carbons in length, they can be used for jet fuel [36]. Alkenones also have competitive thermal properties similar to other commonly used petroleum-derived phase change materials (PCMs) [37]. 


\section{Personal Care Products}

The chemical and physical properties of alkenones that were derived from Isochrysis sp. physical have been characterized in terms of melting point, thickening capability of emulsions, viscosity and stability in personal care products. These results lead to alkenones being investigated in sunscreens combined with three "reef safe" UV filters [37]. The results from that study indicated that alkenones significantly increased the in vitro sun protection factor of the three "reef-safe" UV filters. Currently, there have only been limited studies on alkenones from Isochrysis galbana for medical applications. In a recent pilot study in female Sprague Dawley rats with these alkenones, we found that alkenones were safe following oral and dermal application (unpublic shed findings). Other studies have focus on two vital fatty acids, Eicosapentaenoic acid (EPA) [38-40] and docosahexaenoic acid (DHA) [41-44], which can affect blood pressure, lipoprotein metabolism and platelet and endothelial function. It is possible that alkenones derived from Isochrysis could potentially produce similar effects.

\section{Conclusion}

The many valuable compounds that can be derived from marine algae are the reason why agricultural farms are increasing as consumers are turning towards greener products. Alkenones extracted from Isochrysis sp. represent a major category of valuable compounds. Its usage was limited to a powerful paleo-oceanographic tool but has now expanded to biodiesel fuel and personal care products. It will be interesting to see what other fields of research these alkenones will play a role and how they will benefit our way of life.

\section{Acknowledgment}

This work was supported by University of Toledo Start-up funds (F110760) to AKT.

\section{References}

1. Baliga R, Powers SE (2010) Sustainable Algae Biodiesel Production in Cold Climates. International Journal of Chemical Engineering 13.

2. Hu Q Sommerfeld M, Jarvis E, Ghirardi M, Posewitz M, et al. (2008) Microalgal triacylglycerols as feedstocks for biofuel production: perspectives and advances. The Plant Journal 54(4): 621-639.

3. Duong VT, Thomas-Hall SR, Schenk PM (2015) Growth and lipid accumulation of microalgae from fluctuating brackish and sea water locations in South East Queensland-Australia. Front Plant Sci 6: 359.

4. Kim SK WI (2010) Development and biological activities of marinederived bioactive peptides: a review. Journal of Functional Foods 1-9.

5. Kim S k (2015) Handbook of marine microalgae : biotechnology advances. In: Academic Press, Boston, Massachusetts, P. 585.

6. Gellenbeck K, Salter-Venzon D, Lala R, Chavan J (2012) A multicarotenoid beadlet for human nutrition - proof of concept of in vitro timed release. Acta Biochim Pol 59(1): 35-38.

7. Patras D, Moraru VC, Socaciu C (2018) Screening of Bioactive Compounds Synthesized by Microalgae: a Progress Overview on Extraction and Chemical Analysis. Studia Universitatis Babeș-Bolyai Chemia 63: 21-35.
8. Sosa-Hernandez JE, Escobedo-Avellaneda Z, Iqbal HMN, Welti-Chanes J (2018) State-of-the-Art Extraction Methodologies for Bioactive Compounds from Algal Biome to Meet Bio-Economy Challenges and Opportunities. Molecules 23(11).

9. Hartmann A, Becker K, Karsten U, Remias D, Ganzera M (2015) Analysis of Mycosporine-Like Amino Acids in Selected Algae and Cyanobacteria by Hydrophilic Interaction Liquid Chromatography and a Novel MAA from the Red Alga Catenella repens. Mar Drugs 13(10): 6291-6305.

10. Ullah S, Khalil AA, Shaukat F, Song Y (2019) Sources, Extraction and Biomedical Properties of Polysaccharides. Foods 8(8).

11. Aussant J, Guiheneuf F, Stengel DB (2018) Impact of temperature on fatty acid composition and nutritional value in eight species of microalgae. Appl Microbiol Biotechnol 102(12): 5279-5297.

12. Berthon JY, Nachat Kappes R, Bey M, Cadoret JP, Renimel I, et al. (2017) Marine algae as attractive source to skin care. Free Radic Res 51(6): 555-567.

13. Gutierrez-Rodriguez AG, Juarez-Portilla C, Olivares-Banuelos T, Zepeda RC (2018) Anticancer activity of seaweeds. Drug Discov Today 23(2): 434-447.

14. Martinez Andrade KA, Lauritano C, Romano G, Ianora A (2018) Marine Microalgae with Anti-Cancer Properties. Mar Drugs 16(5).

15. Nakamura H, Sawada K, Araie H, Suzuki I, Shiraiwa Y (2015) n-Nonacosadienes from the marine haptophytes Emiliania huxleyi and Gephyrocapsa oceanica. Phytochemistry 111: 107-113.

16. Marlowe IT, Green JC, Neal AC, Brassell SC, Eglinton G, et al. (1984) Long chain (n-C37-C39) alkenones in the Prymnesiophyceae. Distribution of alkenones and other lipids and their taxonomic significance. British Phycological Journal 19(3): 203-216.

17. Richter N, Longo WM, George S, Shipunova A, Huang Y, Amaral Zettler L (2019) Phylogenetic diversity in freshwater-dwelling Isochrysidales haptophytes with implications for alkenone production. Geobiology

18. Yaakob Z, Ali E, Zainal A, Mohamad M, Takriff MS (2014) An overview: biomolecules from microalgae for animal feed and aquaculture. Journal of Biological Research 21(1): 6.

19. Fidalgo JP, Cid A, Torres E, Sukenik A, Herrero C (1998) Effects of nitrogen source and growth phase on proximate biochemical composition, lipid classes and fatty acid profile of the marine microalga Isochrysis galbana.Aquaculture 166(1): 105-116.

20. Jeffrey SW, Brown MR, Volkman JK (1994) Haptophytes as feedstocks in mariculture. In: Green JC, Leadbeater BSC (eds.) The haptophyte algae Systematics Association Special Volume Oxford, Clarendon Press, UK,Pp. 287-302.

21. Sun Z, Wei H, Zhou ZG, Ashokkumar M, Liu J (2018) Screening of Isochrysis Strains and Utilization of a Two-Stage Outdoor Cultivation Strategy for Algal Biomass and Lipid Production. Appl Biochem Biotechnol 185(4): 1100-1117.

22. Borowitzka MA (1997) Microalgae for aquaculture: Opportunities and constraints. Journal of Applied Phycology 9(5): 393.

23. O Neil GW, Williams JR, Wilson-Peltier J, Knothe G, Reddy CM (2016) Experimental Protocol for Biodiesel Production with Isolation of Alkenones as Coproducts from Commercial Isochrysis Algal Biomass. Journal of Visualized Experiments 112.

24. McIntosh K, Smith A, Young LK, Leitch MA, Tiwari AK, et al. (2018) Alkenones as a Promising Green Alternative for Waxes in Cosmetics and Personal Care Products. Cosmetics 5(2): 34.

25. O Neil GW, Williams JR, Craig AM, Nelson RK, Gosselin KM, et al. (2017) Accessing Monomers, Surfactants, and the Queen Bee Substance by 
Acrylate Cross-Metathesis of Long-Chain Alkenones. Journal of the American Oil Chemists Society 94(6): 831-840.

26. Brassell SC, Eglinton G, Marlowe IT, Pflaumann U, Sarnthein M (1986) Molecular stratigraphy: a new tool for climatic assessment. Nature 320(6058): 129-133.

27. Grossi V, Raphel D, Aubert C, Rontani JF (2000) The effect of growth temperature on the long-chain alkenes composition in the marine coccolithophorid Emiliania huxleyi. Phytochemistry 54(4): 393-399.

28. Volkman JK, Barrerr SM, Blackburn SI, Sikes EL (1995) Alkenones in Gephyrocapsa oceanica: Implications for studies of paleoclimate. Geochimica et Cosmochimica Acta 59(3): 513-520.

29. Zheng Y, Dillon JT, Zhang Y, Huang Y (2016) Discovery of alkenones with variable methylene-interrupted double bonds: implications for the biosynthetic pathway. J Phycol 52(6): 1037-1050.

30. Theroux S, J D Andrea W, Jaime T, Amaral-Zettler L, Huang Y (2010) Phylogenetic diversity and evolutionary relatedness of alkenoneproducing haptophyte algae in lakes: Implications for continental paleotemperature reconstructions. Earth and Planetary Science Letters 300: 311-320.

31. Lee Y K (1997) Commercial production of microalgae in the AsiaPacific rim. Journal of Applied Phycology 9(5): 403-411.

32. Rosen G, Dolecal RE, Colvin MA, George RD (2014) Preliminary ecotoxicity assessment of new generation alternative fuels in seawater Chemosphere 104: 265-270.

33. Mahla SK, Dhir A (2019) Performance and emission characteristics of CNG-fueled compression ignition engine with Ricinus communis methyl ester as pilot fuel. Environ Sci Pollut Res Int 26(1): 975-985.

34. Mimouni V, Ulmann L, Pasquet V, Mathieu M, Picot L, et al. (2012) The potential of microalgae for the production of bioactive molecules of pharmaceutical interest. Curr Pharm Biotechnol 13(15): 2733-2750.

35. Harris J, Vine K, Champagn P, Jessop PG (2018) Advances in microalgal lipid extraction for biofuel production:a review. Bioref 12(6): 11181135.

This work is licensed under Creative

Commons Attribution 4.0 Licens

DOI: 10.19080/OFOAJ.2019.10.555792
36. O Neil GW, Culler AR, Williams JR, Burlow NP, Gilbert GJ, et al. (2015) Production of Jet Fuel Range Hydrocarbons as a Coproduct of Algal Biodiesel by Butenolysis of Long-Chain Alkenones. Energy \& Fuels 29(2): 922-930.

37. O Neil GW, Yen TQ Leitch MA, Wilson GA, Brown EA, et al. (2019) Alkenones as renewable phase change materials. Renewable Energy 134: 89-94.

38. Huynh A, Abou-Dahech MS, Reddy CM, O Neil GW, Chandler M (2019) Alkenones, a Renewably Sourced, Biobased Wax as an SPF Booster for Organic Sunscreens. Cosmetics 6(1): 11.

39. Kostetsky E, Chopenko N, Barkina M, Velansky P, Sanina N (2018) Fatty Acid Composition and Thermotropic Behavior of Glycolipids and Other Membrane Lipids of Ulva lactuca (Chlorophyta) Inhabiting Different Climatic Zones. Mar Drugs 16(12).

40. Walker CG, Jebb SA, Calder PC (2013) Stearidonic acid as a supplemental source of omega- 3 polyunsaturated fatty acids to enhance status for improved human health. Nutrition 29(2): 363-369.

41. Wiese DM, Lashner BA, Lerner E, DeMichele SJ, Seidner DL (2011) The effects of an oral supplement enriched with fish oil, prebiotics, and antioxidants on nutrition status in Crohn's disease patients. Nutr Clin Pract 26(4): 463-473.

42. Jia X, Kohli P, Virani SS (2019) Omega-3 Fatty Acid and Cardiovascular Outcomes: Insights From Recent Clinical Trials. Curr Atheroscler Rep 21(1): 1.

43. Lee HJ, Han YM, An JM, Kang EA, Park YJ, et al. (2018) Role of omega-3 polyunsaturated fatty acids in preventing gastrointestinal cancers: current status and future perspectives. Expert Rev Anticancer Ther 18(12): 1189-1203.

44.Zhang YP, Lou Y, Hu J, Miao R, Ma F (2018) DHA supplementation improves cognitive function via enhancing Abeta-mediated autophagy in Chinese elderly with mild cognitive impairment: a randomised placebo-controlled trial. J Neurol Neurosurg Psychiatry 89(4): 382388.

\section{Your next submission with Juniper Publishers} will reach you the below assets

- Quality Editorial service

- Swift Peer Review

- Reprints availability

- E-prints Service

- Manuscript Podcast for convenient understanding

- Global attainment for your research

- Manuscript accessibility in different formats

( Pdf, E-pub, Full Text, Audio)

- Unceasing customer service

Track the below URL for one-step submission

https://juniperpublishers.com/online-submission.php 